Fallahi, E., M. Kilby, and J.W. Moon. 1990. Effects of various chemicals on dormancy, maturity and thinning of peaches. Deciduous Fruit and Nut. University of Arizona, College of Agr. Rpt., Ser. P-83, p. 121-128.

Fallahi, E., R.R. Lee, and G.A. Lee. 1998. Commercial-scale use of hydrogen cyanamide for blossom thinning of apple and peach. HortTechnology 8:556-560.

Fallahi, E., B.R. Simons, J.K. Fellman, W.M. Colt. 1992. Use of hydrogen cyanamide for apple and plum thinning. Plant Growth Regulat. 11:435-439.

Fallahi, E., M.W. Williams, and W.M. Colt. 1997. Blossom thinning of 'Law Rome Beauty' apple with hydrogen cyanamide and monocarbamide dihydrogensulfate. J. Tree Fruit Prod. 2:33-44.

Ferree, D.C. 1996. Performance of benzyladenine as a chemical thinner on eight apple cultivars. J. Tree Fruit Prod. 1:33-50.

Greene, D.W. 1984. Microdroplet application of $\mathrm{GA}_{4+7}+$ BA: Sites of absorption and effects on fruit set, size, and shape of 'Delicious' apples. J. Amer. Soc. Hort. Sci. 109: 28-30.

Greene, D.W., K.I. Hauschild, and J. Krupa. 2001. Effect of blossom thinners on fruit set and fruit size of peaches. HortTechnology 11:179-183.

Greene, D.W. and W.J. Lord. 1985. Effects of chemical thinners on 'Delicious' apple trees previously sprayed with $\mathrm{GA}_{4+7}+\mathrm{BA}$. HortScience 20:84-86.

Hildebrand, E.M. 1944. The mode of action of the pollenicide, Elgetol. Proc.
Amer. Soc. Hort. Sci. 45:53-58.

Johnson, S. 1998 Consistent tonnage needed for profitability. Good Fruit Grower 49(7):9-10.

Looney, N. 1998. Chemical thinning of 'Fuji' apple. Compact Fruit Tree. Proc. Annu. Conf. Intl. Dwarf Tree Assn. 30:55-57.

Sanderson, P. 1998. Consistent tonnage needed for profitability. Good Fruit Grower 49(7):9-10.

Southwick, S.M., K.G. Weis, J.T. Yeager, and M.E. Rupert. 1998. Blossom thinning of 'Loadel' cling peach with a surfactant: Effects of concentration, carrier volume, and differential applications within the canopy. HortTechnology 8:55-58.

Taylor, J. 1998. Consistent tonnage needed for profitability. Good Fruit Grower 49(7):9-10.

Williams, K.M. 1998. Blossom thin for consistent crops. Good Fruit Grower 49(7):8.

Williams, M.W. 1993. Comparison of NAA and carbaryl petal-fall sprays of apples. HortTechnology 3:428-429.

Williams, M.W. 1994. Factors influencing chemical thinning and update on new chemical thinning agents. Compact Fruit Tree 27:115-122.

Williams, M.W. and Edgerton. 1981. Fruit thinning of apples and pears with chemicals. U.S. Dept. Agr., Agr. Bul. 289.

\title{
Chemicals, Timing, and Environmental Factors Involved in Thinner Efficacy on Apple
}

\author{
Duane W. Greene \\ Department of Plant and Soil Sciences, University of Massachusetts, Amherst, MA 01003
}

\begin{abstract}
Apple (Malus $\times$ domestica Borkh.) is a biennial bearing tree. This is characterized by heavy bloom in the 'on' year which generally leads to an overset of fruit. There are several negative consequence associated with overcropping. Many small fruit are produced, that ripen late, have poor appearance and quality, and are worth little when sold as fresh fruit. Further, flower bud formation is significantly reduced, if not totally inhibited, for the following year. Reduced cropping in the "off" year may lead to significant lower cropping, and inferior quality fruit that has a reduced postharvest storage life. In high density plantings, excessive vegetative growth may occur on lightly-cropped trees, making future management of the block difficult.

Over 50 years of experience has shown that chemical regulation of cropping is the only practical way to break this biennnial bearing cycle and reestablish more regular cropping. However, the challenges posed by chemical thinning are among the greatest obstacles fruit growers face in achieving profitable production. The chemicals and concentrations a grower chooses, the timing of their application, and the environmental factors encountered before, during, and after application all influence the ultimate thinning response. This communication will discuss the chemicals most frequently used, the circumstances when they are used and the precautions associated with their use. Also discussed will be the timing of the applications and the environmental factors one must be mindful of when applying chemical thinners.
\end{abstract}

\section{THINNING CHEMICALS}

Blossom thinners. Some of the first attempts to reduce biennial bearing involved using caustic chemicals to prevent pollination, pollen germination or pollen tube growth (MacDaniels and Hildebrand, 1940). Many of these caustic chemicals caused unacceptable phytotoxicity to the leaves and caused russeting of the fruit. The product sodium dinitroortho-cresolate (DNOC), sold commercially as Elgetol (FMC Corp., Chicago), ultimately became the material that was adopted as the blossom thinner of choice for general commercial use (Batjer and Hoffman, 1951). DNOC was used extensively in the arid fruit growing areas in western North America, but its use never became a commercial practice in the east for several reasons. Erratic weather during the bloom

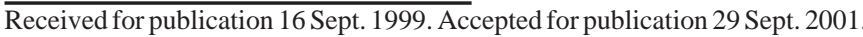

period made it difficult to determine the extent of set until after the window of opportunity for application of Elgetol passed. More phytotoxicity was encountered in the east where drying times are longer due, in large part, to the higher humidity. If rains followed application even greater phytotoxicity and excessive thinning were frequently experienced. Elgetol was removed by the manufacturer from the market in 1989 due to the high cost of reregistration. This resulted in renewed interest in identifying a safe and effective blossom thinner to replace Elgetol.

The search for replacements for Elgetol continues. Wilthin (monocarbamide dihydrogen sulfate) has proven to be an effective blossom thinner on several apple cultivars ( Byers, 1997; Fallahi et al., 1997; Williams, 1993). The herbicide endothall (7, oxabicyclo $(2,2,1)$ heptane-2-3 dicarboxylic acid) has thinning activity and commercial promise ( Byers, 1997; Williams et al., 1995). Other potential blossom thinners include pelargonic acid (MYX4801) (Byers, 1997), ammonium thiosulfate (ATS) (Byers, 1997), and Dormex (hydrogen cyanimide) (Fallahi, 1998; Fallahi et al., 1997). While all of these compounds have significant thinning activity, only after further multiple experiments conducted over several years, and under differing environmental conditions, will it be possible to determine if these blossom thinners fit into the overall thinning scheme. Most important, we must know if they can be relied on to be consistently effective.

While less frequently used, hormone sprays can thin when applied at bloom. Burkholder and McCown (1941) showed that a bloom spray of NAA and NAAm could reduce set. While this has been confirmed by later research (Jones et al., 1992), these two compounds are generally not applied commercially during bloom because of grower uncertainty about the extent of initial set and the desire to assess initial set before attempting to adjust crop load. Further, the most effective time to apply NAA as a chemical thinner is when fruit diameter is 7 to $9 \mathrm{~mm}$ (Leuty, 1973) or 11 to $13 \mathrm{~mm}$ (Tukey, 1965).

Ethephon may also thin when applied at bloom (Jones et al., 1990) or even several days earlier, at the balloon stage (Jones et al., 1983) or red stage (Wertheim, 1973). The response appears to be quite cultivar (Link, 1978) and temperature (Jones and Koen, 1985) sensitive. The use of ethephon as a blossom thinner has not be widely adopted except in locations where chemical thinning with other compounds is difficult and satisfactory results using other thinners is generally inadequate. 
Postbloom thinners. The majority of thinning that is done commercially for the past 50 years is with postbloom thinners. There is a comfort level for growers to delay thinner application until they can know the weather conditions during bloom and bee activity.

Naphthaleneacetic acid (NAA). NAA was the first hormone-type thinner to be adopted and used commercially (Burkholder and McCowan, 1941). It is probably the most potent of the general-use thinners on the market today and it is the preferred material for cultivars that are difficult to thin (Forshey and Hoffman, 1966). It is used at concentrations ranging from 2 to $20 \mathrm{mg} \cdot \mathrm{L}^{-1}$ and its thinning effectiveness is linear with concentration (Forshey, 1986). However, under most commercial thinning situations the concentration range used is 5 to $12 \mathrm{mg} \cdot \mathrm{L}^{-1}$. Lower concentration may cause modest thinning while higher concentrations may overthin and reduce fruit size or not increase fruit size even though the crop load is substantially reduced (Greene, 1943; Hartmann and Howlett, 1962). Over application of NAA may also lead to pygmy fruit formation and severe leaf epinasty (Marini, 1996, Miller, 1985). Therefore, NAA is often combined with another thinner, especially carbaryl, and used at lower and safer rates (Greene, 1996). The thinning action of NAA is sometimes not immediately apparent since fruit abscission following NAA application if often delayed by as much as one or two weeks relative to untreated trees (Struckmeyer and Roberts, 1950).

Naphthaleneacetamide (NAAm, NAD). Initial testing of NAD was done with NAA, but it was the chemical of choice because NAD is a less potent thinner than NAA. NAD is applied at rates up to $100 \mathrm{mg} \cdot \mathrm{L}^{-1}$ but the concentration range normally used is between 35 to $50 \mathrm{mg} \cdot \mathrm{L}^{-1}$ (Forshey, 1986). NAD is a useful thinner that is frequently applied as a petal-fall spray (Forshey, 1986; Hoffman, 1953). It is considered safer to use than NAA and it does not cause as severe leaf epinasty following application that is often experienced with NAA (Batjer and Billingsley, 1964). NAD is never used on 'Delicious' since it can result in a high percentage of pygmy fruit that persist to harvest (Williams and Edgerton, 1981). Like NAA, NAD is frequently combined with carbaryl in situations were more aggressive thinning is desired. In general, NAD is an underutilized chemical thinner and further research may show how this chemical can be more effectively used and integrated into a chemical thinning program.

Carbaryl. Carbaryl is the most versatile thinner in general use. It is a mild thinner, and since the thinning is not rate responsive, overthinning is rarely observed (Forshey, 1986). It can be used effectively over a wide range of developmental stages from petal fall until fruit are $18 \mathrm{~mm}$ in diameter (Knight and Spencer, 1987). It is very toxic to bees so the earliest time of application is at petal fall after the bees have been removed from the orchard. The Sevin XLR Plus (Adventis CropScience USA, Research Triangle Park, N.C.) formulation may be less of a problem near bloom since the particle size is less like pollen thus it is less likely to be transported by bees back to the hive. One of the most important characteristics of carbaryl is that it can break up fruit clusters (Looney and Knight, 1985; Williams, 1994). Carbaryl appears to be most effective when applied to the fruit but under cloudy or shady conditions, carbaryl applied to the spur leaves may contribute to the thinning response (Byers et al., 1990). Carbaryl is an insecticide rather than a hormone so it is applied at higher concentrations than other postbloom thinners. Generally it is applied at dilute concentrations equivalent to 561 to $1121 \mathrm{~g} / 379 \mathrm{~L}$.

Benzyladenine (BA, Accel). Benzyladenine is the newest thinner to be introduced. It was initially identified as a promising chemical thinner because it reduced crop load, increased fruit size, and enhanced return bloom (McLaughlin and Greene, 1984). The effective thinning concentration is between 50 and $150 \mathrm{mg} \cdot \mathrm{L}^{-1}$ (Greene and Autio, 1989). BA is applied commercially as the proprietary product Accel, which contains $90 \%$ BA and $10 \%$ GA4+7 . The commercial debut of Accel was less successful than one would anticipate from previous thinning reports (Elfving and Cline, 1993; Greene, 1993, Mclaughlin and Greene, 1991). The label initially allowed only 49 grams active ingredient (gai)/ha per application, a marginally effective amount, based upon previous experience. The label was amended to allow $74 \mathrm{gai} / \mathrm{ha}$, which is closer to that necessary for effective thinning when used by itself. There is also reason to believe that the small amount of GA present in the formulation may partially negate the thinning effects of BA (Terence Robinson, personal communication). BA is a mild thinner when used by itself, but when combined with carbaryl is potent thinner that can overthin (Byers and Carbaugh, 1991; Greene and Autio, 1994). The combination of BA with NAA for use on 'Delicious' and 'Fuji' is not recommended since pygmy fruit may form in some circumstances (Greene and Autio, 1994). Unlike other thinners, BA can increase fruit size beyond that attributed to a reduction in crop load (Greene, 1993).

Ethephon. Ethephon is generally not considered a mainstream postbloom thinner in most apple growing regions. However, it is recommended as a postbloom thinner in areas and in situations where other chemical thinners are less effective or have undesirable side effects (Jones et al., 1983; Unrath, 1978). Ethephon has a reputation for being an erratic thinner. Part of this can be attributed to a dramatic increase in thinning response with increasing temperature following application (Jones and Keon, 1986). Also, flowers and fruit susceptibility to ethephon varies depending upon the stage of development. Ethepon is an effective blossom thinner (Jones et al., 1990) but application made just $7 \mathrm{~d}$ later appear to be ineffective (Bound et al., 1993b). Fruit redevelop thinning sensitivity to ethephon at diameters between 16 and $22 \mathrm{~mm}$ (Marini, 1996). Since larger fruit are sensitive to ethephon, unlike most other chemical thinners, ethephon may have a place in a normal chemical thinning program as a "last chance" thinner where other thinners do not work or where a grower made a miscalculation early in the season, and failed to apply a thinner at the normal time.

\section{TIME OF APPLICATION}

Chemical thinners may be applied over a relatively wide range of time, and depending on the year, this may be from bloom until fruit reach a diameter of up to $25 \mathrm{~mm}$ (Schwailler, 1996). The weather largely determines the length of the thinning window of opportunity. If the weather following bloom remains relatively cool and sunny, fruit growth is slow, and developing fruit are placed under little stress so thinning can be carried out over a long period of time. Conversely, if the weather is warm to hot following bloom, fruit growth is rapid, fruit are stressed by competition with other fruit and growing shoots, and the time period when fruit can be thinned is shortened.

The weather following thinner application is probably the single most important factor influencing thinner efficacy and the extent of June drop (Greene, 1996; Schwallier, 1996). The weather can not be regulated, and an accurate forecast of the weather usually does not extend beyond 2 or $3 \mathrm{~d}$. Recently, there has been a trend for growers in the eastern part of the United States to make two or more thinner applications over the thinning period. This has been done on the west coast for many years. This is a good strategy since it spreads thinning out over time, and increases the possibility that thinner application will coincide with favorable thinning weather. It also tends to be safer since less aggressive thinning treatments are generally used, and the chance of overthinning is reduced.

Growth and development of fruit during the thinning period is dynamic and continuous. There are specific times during this developmental process when fruitlets may be especially vulnerable to chemicals with specific modes of action, while at other times all thinners may be effective. Each time period during the developmental process provides thinning opportunities, and strategies may be devised to thin at these times.

Bloom. Blossom thinning offers several advantages over thinning at other times. Early flower/fruit removal usually results in the largest fruit at harvest and the greatest return bloom the following year (Batjer and Hoffman, 1951). Efficacy of blossom thinners is less influenced by the weather than hormone-type thinners, and to be effective, it may not be necessary to have specific physiological conditions exist within the fruit. Outside of the Pacific Northwest, there has been grower reluctance to embrace blossom thinners for several reasons. The potential for undesirable phytotoxic effects is generally higher in humid regions such as in the eastern or midwestern United States (Byers, 1997). Also, weather during bloom is less predictable. The possibility of frost still exists and the occurrence of rain and the development of backdoor cold fronts are prevalent on the Atlantic coast at this time of year. These may 
bring in cool, wet weather during the pollination period.

The strategy used in applying caustic thinners at bloom is to allow pollination of the king flower, and then apply a blossom thinner to prevent pollination or to inhibit pollen tube growth in the style of side flowers (Williams and Edgerton, 1981). Generally, blossom thinners are applied at $70 \%$ to $90 \%$ bloom (Byers, 1997; Fallahi et al., 1997; Williams et al., 1995). A delay in application until full bloom or later may have two consequences. First, thinners are less effective when applied at this time. Second, the likelihood of russet or fruit marking at harvest is increased (Byers, 1997; Fallahi et al., 1997; Williams et al., 1995). In some areas chilling is less intense, and flowers open over an extended period of time. In these situations, two applications of a blossom thinners may be more effective than one (Byers, 1997; Williams, 1993).

Bees are in the orchard during the bloom period. Therefore, the use of chemicals toxic to bees should be avoided. It is for this reason that carbaryl is never used at bloom.

Petal fall to $5 \mathrm{~mm}$. On any one cultivar petal fall is an easily defined event associated with the dropping of the petals. However, from a chemical thinning standpoint petal fall is much more nebulous because petal fall in an orchard may occur over several days because of differing bloom times of cultivars usually found in an orchard. From a practical and chemical thinning standpoint, petal fall should be considered the time when the bees are removed from the orchard.

Thinners have been successfully applied at petal-fall for many years (Thompson, 1957). There are many reasons why this may be a preferred time to apply chemical thinners. This is the first time a grower can apply a thinner with some knowledge about the bloom period, and thus the potential crop for the year. Early applications of thinners generally mean larger fruit at harvest and greater return bloom (Batjer and Hoffman, 1951). This is especially true for early maturing cultivars, and those that have a strong biennial bearing tendency. In areas where blossom thinning is not routinely used, this is generally considered the earliest opportunity growers have to chemically thin (Schwallier, 1996).

Several chemicals can be used at petal-fall. Carbaryl can thin over a relatively long period (Forshey, 1987). Knight and Spencer (1987) and Williams (1993) established that it was especially useful as a petal fall spray. Petal fall application of carbaryl is considered the cornerstone treatment in the "nibble" approach to chemical thinning recommended in many places in the eastern United States (Greene, 1997). It has been adopted by a large percentage of growers in New England (Greene, 1996). Petal fall sprays of NAA are effective (Southwick and Weeks, 1949), but at effective concentrations they may be more erratic than carbaryl (Williams, 1993). When applied at petal fall NAA may cause severe leaf epinasty on susceptible cultivars. For this reason, NAD is often used at petal fall instead of NAA (Hoffman, 1953; Thompson, 1957). Where aggressive thinning seems appropriate, carbaryl with reduced rates of NAA has been successful. In general, BA has not been especially effective as a thinner when applied at petal fall (Bound et al., 1993a; Greene and Autio, 1989).

Seven to $12 \mathrm{~mm}$. Historically, this is the time when most chemical thinners have been applied (Williams and Edgerton, 1981). This usually occurs 7 to $21 \mathrm{~d}$ after bloom. It is the time when most chemical thinners are effective. During this period of time, shoots and fruit are rapidly growing and there is active competition among these for the available carbohydrate (Corelli Grappadelli et al., 1994). Demand for carbohydrate may exceed supply, especially on warm days when respirational losses are high and photosynthesis is occurring at less than an optimal rate. NAA is most effective when applied at this time (Leuty, 1973; Tukey, 1965). Schneider and Lasheen (1973) showed that NAA reduced the amount of sugar translocated from leaves and Stopar et al. (1997) demonstrated that NAA reduced $\mathrm{CO}_{2}$ assimilation in leaves of 'Delicious' apples. BA is most effective as a chemical thinner when applied at the 7 to $12 \mathrm{~mm}$ stage of fruit development (Bound, et al., 1993a; Greene and Autio, 1989). Yuan and Greene (2000) showed that BA reduced net photosynthesis in 'McIntosh' apples primarily by increasing carbon consumption through increased dark respiration. While the mode of action of carbaryl has not been established, Williams and Batjer (1964) found evidence that the translocation of metabolites including sugars may be blocked when carbaryl was applied to fruit.
Therefore, peak thinning activity of the major chemical thinners used at this time (NAA, carbaryl, and BA) is consistent with the suggestion that they exert their thinning response by reducing available carbohydrate thus intensifying competition among the competing sinks including developing fruit.

It is generally accepted that the fruit size increase realized by the application of chemical thinners is due primarily to a reduction in crop load. BA like other thinners increases fruit size in this manner. However, BA is a cytokinin, and it does increase cell division and it is especially effective when applied during this time (Greene, 1993). Wismer et al. (1995) showed that BA increased fruit size by increasing the number of cortical cells, and the optimum time of application coincided with a very active period of cell division in 'Empire' apples.

Fourteen to $18 \mathrm{~mm}$. There is general agreement that this is a marginal time to apply a chemical thinner. Numerous reports confirm that chemical thinners diminish in effectiveness as fruit size increases to the 14 to $18 \mathrm{~mm}$ stage of fruit development. Some June drop has occurred and growth of other fruit destined to drop has slowed or stopped, indicating that subsequent fruit drop has been at least partially predetermined. Successful fruit thinning at this stage of fruit development with NAA, BA, and possibly carbaryl, is generally restricted to years where the weather has been sunny and cool, and fruit to this point have not been subjected to stress. However, Byers and Carbaugh (1991) and Marini (1996) have reported that application at this time with ethephon or ethephon with carbaryl may result in good and successful thinning. NAA if applied at this time may result in a reduction in fruit size (Luckwill, 1953). This situation can be further exacerbated if NAA is applied at relatively high concentrations in warm temperatures (Black et al., 1995).

Twenty millimeters and larger. When fruit reach this size, only ethephon or ethephon with carbaryl will consistently thin apples (Marini, 1996). Experience in New England at this stage of fruit development indicates that concentrations between 250 and $500 \mathrm{mg} \cdot \mathrm{L}^{-1}$ may or may not thin, but there is the likelihood on some cultivars of advancing ripening and advancing preharvest drop (Lord et al., 1975). Lehman et al. (1987) reported that heavy shading of spur 'Delicious' trees during this period of fruit development may make trees more susceptible to a thinning treatments containing ethephon and carbaryl.

\section{ENVIRONMENTAL FACTORS}

Environmental influences on chemical thinning are the most difficult to document since we have no control over the weather. Control of all environmental factors under field conditions is challenging and frequently not possible. Alternatively, numerous observations must be made under widely differing conditions in the field, and this is a very time-consuming and haphazardous process.

Before application. Even in the infancy of chemical thinning researchers and orchardists recognized that weather conditions prior to spray application influenced the thinning response (Batjer and Hoffman, 1951). Cool, cloudy, wet periods preceding thinner application generally mean that thinning will be easier (Thompson, 1957). Part of this is attributed to epicuticular wax and cuticle development which predisposes leaves to absorb more thinning chemical (Westwood et al., 1960). These conditions during and immediately after bloom may also lead to less vigorous fruit set, characterized by fruit that are not growing vigorously and have few seeds, increased seed abortion, and reduced carbohydrate (Batjer and Billingsley, 1964; Forshey, 1986). Regardless of thinner absorption, these fruit will be easier to thin. Frost injury to spur leaves also will make fruit easier to thin (Williams and Edgerton, 1981). NAA penetration is greater into frost injured leaves (Westwood and Batjer, 1960) and the markedly distorted spur leaves undoubtedly have a reduced photosynthetic capacity.

Fruit must have rapid and consistent growth to persist. Warm, sunny weather following bloom is conducive to rapid fruit growth and a good fruit set. These fruit are more difficult to thin (Williams and Edgerton, 1981).

Environmental conditions at the time of application. The two most important environmental factors that influence foliar penetration of a chemical thinner are temperature and drying time. Warm temperatures enhance uptake of NAA (Black et al, 1995; Westwood and Batjer, 
1960) and dinitro-o-cresol (Westwood and Batjer, 1958) by apple leaves. The longer the drying time of a thinning spray the greater the penetration into the leaf (Westwood and Batjer, 1960). In foliar penetration studies on pear (Pyrus communis L.) leaves, it was found that the penetration of NAD increased steadily over time as long as the spray droplet was prevented from drying (Greene and Bukovac, 1971). During the drying process uptake into the leaf was accelerated, presumably due to the concentration effect caused by the drying. Once the droplet dried, little additional penetration occurred. Therefore, the longer the time before droplet drying, the greater the penetration.

Warm temperatures conducive to increased foliar penetration are usually accompanied by rapid drying conditions. Conversely, slow drying conditions in the field are usually at night when temperatures are cooler. One unpublished study done by the author on the penetration of BA into leaves of 'McIntosh' apples during the day and night revealed that it made no difference what time during the day or night BA was applied, the amount entering the leaf was the same. Apparently, increased penetration due to higher temperatures during the day were offset by reduced drying times. Conversely, the increased penetration do to increased drying time at night was negated by the reduced penetration under cooler temperatures. Thus, it appears that it does not make any difference when you apply a chemical thinning spray, as long as it is not too windy.

Weather conditions following application. Temperature following thinner application is the dominant factor influencing the response to a chemical thinner (Forshey, 1986; Greene, 1996; Williams, 1994). Elevated temperatures provides the stress required for thinners to work (Williams, 1994). Warm temperatures intensify competition among competing sinks at a time when metabolic demand is highest in the tree. If cool weather follows thinner application, thinning results are frequently disappointing. It is often better to wait 2 or $3 \mathrm{~d}$ until warm temperatures are forecast to occur after application than to apply a thinner when cool conditions prevail immediately after application (Forshey, 1986). Byers (1998) has suggested that warm temperatures at night may be even more important than day temperature in favoring a good thinner response.

It is not uncommon to have several days of cloudy weather during the bloom period where incoming solar radiation is reduced to $10 \%$ to $15 \%$ of full sun. Several reports have documented that this shading can intensify June drop. Lehman et al. (1987) doubled drop by applying $73 \%$ shade to 'Starkrimson Delicious' from 17 to $35 \mathrm{~d}$ after bloom. Byers et al. (1990; 1991) increased drop by shading trees with $83 \%$ to $92 \%$ shade for periods of 2 to $4 \mathrm{~d}$ during the June drop period. Applying chemical thinning sprays on shaded trees enhanced the abscissionpromoting effect of the thinners (Byers et al., 1990, 1991; Lehman et al., 1987). Therefore, it may be advisable to delay thinner application in circumstances where trees have been exposed to several days of shading to avoid overthinning. One or two days of sun following shading partially reversed the abscission-promoting effect of shading (Byers et al., 1991).

Orchardists generally try to apply thinners well in advance of rain, but occasionally this cannot be avoided. It is my experience that if a chemical thinner dries on the leaf prior to the onset of rain, one can anticipate getting at least $80 \%$ of the thinning effect. Unrath (1981) is in general agreement with this observation, but ethephon may be an exception since at least $4 \mathrm{~h}$ after drying was required for the ethephon response. Ethephon is a very water soluble compound. Material deposited on leaves may be rewetted, resulting in additional absorption. This has been documented with dinitro-o-cresol where rain occurring $1 \mathrm{~d}$ after application resulted in increased absorption (Westwood and Batjer, 1958). Increased absorption of carbaryl may also occur by rewetting. Periods of damp, drizzly weather, with precipitation sufficient to keep foliage wet but not enough to wash off residues, may significantly increase thinning (Forshey, 1986).

\section{Literature Cited}

Batjer, L.P. and H.D. Billingsley. 1964. Apple thinning with chemical sprays. Washington State Agr. Expt. Sta. Bul. 651.

Batjer, L.P. and M.B. Hoffman. 1951. Fruit thinning with chemical sprays. U.S. Dept. Agr. Circ. 867, Washington, D.C.
Black, B., P.D. Petracek, and M.J. Bukovac. 1995. The effect of temperature or uptake of NAA by Redchief 'Delicious' apple leaves. J. Amer. Soc. Hort. Sci. 120:441-445.

Bound, S.A., K.M. Jones, B. Graham, M.J. Oakford, and M. Tichon. 1993a. Modeling the effects of timing and roles of application of benzyladenine as a secondary thinner of 'Fuji' apples after ethephon. J. Hort. Sci. 68:967-973.

Bound, S.A., K.M. Jones, M.J. Oakford, and M. Tichon. 1993b. Assessing interactive effects between Cytolin and ethephon on cropping red 'Delicious'. J. Hort. Sci. 68:209-213.

Burkholder, C.L. and M. McCown. 1941. Effects of scoring and of a naphathyl acidic acid and amide spray upon fruit set and of the spray upon pre-harvest fruit drop. Proc. Amer. Soc. Hort. Sci. 38:117-120.

Byers, R.E. 1997. Effects of bloom-thinning chemicals on apple fruit set. J. Tree Fruit Prod. 2(1):13-31

Byers, R.E. 1998. The influence of temperature and low light on fruit retention and chemical thinning of apple trees. Proc. Plant Growth Regulat. Soc. Amer. 25:34-35.

Byers, R.E., J.A. Barden and D.H. Carbaugh. 1990. Thinning of spur 'Delicious' apples by shade, terbacil, carbaryl and ethephon. J. Amer. Soc. Hort. Sci. 115:9-13. Byers, R.E. and D.H. Carbaugh. 1991. Effect of chemical thinning sprays on apple fruit set. HortTechnology 1:41-48.

Byers, R.E., D.H. Carbaugh, C.N. Presley, and T.K. Wolf. 1991. The influence of low light on apple fruit abscission. J. Hort. Sci. 66:7-17.

Corelli Grappadelli, L., A.N. Lakso, and J.A. Flore. 1994. Early season patterns of carbohydrate partitioning in exposed and shaded apple branches. J. Amer. Soc. Hort. Sci. 119:596-603.

Elfving, D. C. and R. A. Cline. 1993. Benzyladenine and other chemicals for thinning 'Empire' apple trees. J. Amer. Soc. Hort. Sci. 118:593-598.

Fallahi, E. 1998. The use of blossom thinners for regular cropping of deciduous fruit trees. Proc. Plant Growth Regulat. Soc. Amer. 25:27-33.

Fallahi, E., M.W. Williams, and W.M. Colt. 1997. Blossom thinning of 'Law Rome Beauty' apple with hydrogen cyanamide and monocarbamide dihydrogensulfate. J. Tree Fruit Prod. 2(1):33-44.

Forshey, C.G. 1986. Chemical fruit thinning of apples. New York's Food and Life Sci. Bul. No. 116.

Forshey, C.G. 1987. A review of chemical thinning. Proc. New England Fruit Mtg. 93:68-73.

Forshey, C.G. and M.B. Hoffman. 1966. Factors affecting chemical thinning of apples. New York State Agr. Expt. Sta. Res. Circ. No. 4.

Greene, D.W. 1993. A review of the use of benzyladenine (BA) as a chemical thinner for apples. Acta Hort. 329:231-236.

Greene, D.W. 1996. Chemical thinning of apples in New England. Proc. Michigan State Hort. Soc. 126:99-103.

Greene, D.W. 1997. Chemical thinning strategies for the future. Proc. New England Fruit Mtg. 103:22-26.

Greene, D.W. and W.R. Autio. 1989. Evaluation of benzyladenine as a chemical thinner on 'McIntosh' apples. J. Amer. Soc. Hort. Sci. 114:6873.

Greene, D.W. and W.R. Autio. 1994. Combination sprays with benzyladenine to chemically thin spur-type 'Delicious' apples. HortScience 29:887-890.

Greene, D.W. and M.J. Bukovac. 1971. Factors influencing the penetration of naphthaleneacetamide into leaves of pear (Pyrus communis L.). J. Amer. Soc. Hort. Sci. 96:240-246.

Greene, L. 1943. Growth regulators and fruit set with Starking apples. Proc. Amer. Soc. Hort. Sci. 42:149-150.

Hartmann, F.O. and F.S. Howlett. 1962. Effects of naphthaleneacetic acid on fruit setting and development in the apple. Ohio Agr. Expt. Sta. Bul. 920.

Hoffman, M.B. 1953. Safer thinning sprays for apples. New York State Hort. Soc. Proc. 98:128-135.

Jones, K.M., S.A. Bound, and M.J. Oakford. 1992. Identifying the optimum thinning time for red 'Fuji' apples. J. Hort. Sci. 67:685-694.

Jones, K.M. and T.B. Koen. 1985. Temperature effects on ethephon thinning of apples. J. Hort. Sci. 60:21-24.

Jones, K.M. and T.B. Koen. 1986. Manipulation of blossom density and the effect of ethephon thinning of Golden Delicious. Acta Hort. 179:653-657.

Jones, K.M., T.B. Koen, and R. J. Meredith. 1983. Thinning Golden Delicious apples using ethephon sprays. J. Hort. Sci. 58:381-388.

Jones, K.M., T.B. Koen, M.J. Oakford, and S.A. Bound. 1990. Thinning 'Red Fuji' apples using ethephon at two timings. J. Hort. Sci. 65:381-384.

Knight, J.N. and J.E. Spencer. 1987. Timing of application of carbaryl used as an apple fruitlet thinner. J. Hort. Sci. 62:11-16.

Lehman, L., C.R. Unrath, and E. Young. 1987. Chemical fruit thinning response of spur 'Delicious' apple as influenced by light intensity and soil moisture. HortScience 22:214-215.

Leuty, S.J. 1973. Identification of maximum sensitivity of developing apple fruits to naphthaleneacetic acid. J. Amer. Soc. Hort. Sci. 98:247-252.

Link, H. 1978. Results of thinning apples with some chemical compounds. Acta Hort. 80:283-286.

Looney, N.E. and J.N. Knight. 1985. Effects of initial set and carbaryl treatment 
on final fruit set on 'Greensleeves' apples. HortScience 20(3):400-401.

Lord, W.J., D.W. Greene, and R.A. Damon. 1975. Evaluation of fruit abscission and flower bud promotion capabilities of ethephon and SADH on apples. J. Amer. Soc. Hort. Sci. 100:259-261.

Luckwill, L.C. 1953. Studies on fruit development in relation to plant hormones. II. The effect of naphthaleneacetic acid on fruit set and fruit development in apples. J. Hort. Sci. 28:25-40.

MacDaniels, L.H. and E.M. Hildebrand. 1940. A study of pollen germination on the stigmas of apple flowers treated with fungicides. Proc. Amer. Soc. Hort Sci. 37:137-140.

Marini, R.P. 1996. Chemically thinning spur Delicious apples with carbaryl, NAA, and ethephon at various stages of fruit development. Hort. Technology 6:241-246.

McLaughlin, J.M. and D.W. Greene. 1984. Effects of BA, GA ${ }_{4+7}$, and daminozide on fruit set, fruit quality, vegetative growth, flower initiation, and flower quality of 'Golden Delicious' apple. J. Amer. Soc. Hort. Sci. 109:34-39.

McLaughlin, J.M. and D.W. Greene. 1991. Fruit and hormones influence flowering of apple. II. Effects of hormones. J. Amer. Soc. Hort. Sci. 116:450-453.

Miller, P. 1985. Apple thinning in Australia. Hort. Res. Inst., Knoxfield.

Schneider, G.M. and A.M. Lasheen. 1973. NAA and Sevin on composition, development and abscission of apple fruit. HortScience 8:103-104.

Schwallier, P.G. 1996. Apple Thinning Guide. Great Lakes Publishing Company, Sparta, Mich.

Southwick, F.W. and W.D. Weeks. 1949. Chemical thinning of apples at bloom time and up to four weeks from petal fall. Proc. Amer. Soc. Hort. Sci. 53:143-147.

Stopar, M., B.L. Black, and M.J. Bukovac. 1997. The effect of NAA and BA on carbon dioxide assimilation by shoot leaves of spur-type 'Delicious' and 'Empire' apple trees. J. Amer. Soc. Hort. Sci. 122:837-840.

Struckmeyer, B.E. and R.H. Roberts. 1950. A possible explanation of how naphthalene acetic acid thins apples. Proc. Amer. Soc. Hort. Sci. 56:76-78.

Thompson, A.H. 1957. Six years experiments on chemical thinning of apples. Univ. of Maryland Agr. Expt. Sta. Bul. A-88.

Tukey, L. 1965. Fruit-size timing in chemical thinning of apple trees. Proc.
Illinois Hort. Soc. 99:67-79.

Unrath, C.R. 1978. The development of ethephon's thinning potential for spur 'Delicious' apples. Acta Hort. 80:233-243.

Unrath, C.R. 1981. An overview of environmental factors affecting orchard growth regulator response with special reference to apple. Acta Hort. 120:43-52.

Wertheim, S.J. 1973. Chemical control of flower and fruit abscission in apple and pear. Acta Hort. 34:321-331

Westwood, M.N. and L.P. Batjer. 1958. Factors influencing absorption of dinitro- ortho-cresol and naphthaleneacetic acid by apple leaves. Proc. Amer Soc. Hort Sci. 72:16-29.

Westwood, M.M. and L.P. Batjer. 1960. Effects of environment and chemical additives on absorption of naphthanelenacetic acid by apple leaves. Proc. Amer. Soc. Hort. Sci. 76:16-29.

Westwood, M.N., L.P. Batjer, and H.D. Billingsley. 1960. Effects of environment and chemical additives on absorption of dinitro-o-cresol by apple leaves. Proc. Amer. Soc. Hort. Sci. 76:30-40.

Williams, M.W. 1993. Sulfcarbamide, a blossom-thinning agent for apples. HortTechnology 3:322-324.

Williams, M.W. 1994. Factors influencing chemical thinning and update on new chemical thinning agents. Compact Fruit Tree 27:115-122.

Williams, M.W. and L.P. Batjer. 1964. Site and mode of action of 1-naphthyl$\mathrm{N}$ - methylcambamate (Sevin) in thinning apples. Proc. Amer. Soc. Hort. Sci. 85:1-10.

Williams, M.W., S.A. Bound, J. Hughes and S. Tustin. 1995. Endothall: A blossom thinner for apples. HortTechnology 5(3):257-259.

Williams, M.W. and L.J. Edgerton. 1981. Fruit thinning of apples and pears with chemicals. U.S. Dept. Agr. Bul. 289, Washington, D.C.

Wismer, P.T., J.T.A. Proctor and D. C. Elfving. 1995. Benzyladenine affects cell division and cell size during apple fruit thinning. J. Amer. Soc. Hort. Sci. 120:802-807.

Yuan, R. and D.W. Greene. 2000. Benzyladenine as a chemical thinner for 'McIntosh' apples. I. Fruit thinning effects and associated relationships with photosynthesis, assimilate translocation, and nonstructural carbohydrates. J. Amer. Soc. Hort. Sci. 125:169-176.

\title{
Spray Volume, Canopy Density, and Other Factors Involved in Thinner Efficacy
}

\author{
C.R. Unrath ${ }^{1}$ \\ Department of Horticulture Science, North Carolina State University, \\ Mountain Horticultural Crops Research and Extension Center, 455 Research Drive, Fletcher, NC 28732
}

Historically, a single, arbitrary water volume was used for most airblast chemical applications to apple (Malus $\times$ domestica Borkh.) orchards. Chemical recommendation rates were originally based on a "mythical" $3741 \mathrm{~L} \cdot \mathrm{ha}^{-1}$ water volume for "mature bearing trees". In the early 1970s, we were at a loss to explain the wide variability in chemical thinning response among grower locations to similar treatments (Herrera, 1977). After reviewing an article (Byers, et al., 1968), where canopy volume was related to water volume to illustrate to growers that smaller trees required less water volume than the "mythical, mature bearing" size tree for good pesticide coverage, we began to focus on the relationship of tree size to water volume to explain variability in response to chemical thinners.

Adjustment of water volume to tree size removed the treatment by location interaction in thinning research plots, and for the first time allowed evaluation of mean chemical response over locations (Herrera, 1997). Thus, this "tree row volume" (TRV) concept was developed (Herrera and Unrath, 1980). Subsequently, we found that water volumes used by growers did not vary with tree size. Therefore, most growers were overspraying small trees and underspraying large ones (Sutton and Unrath, 1984).

Received for publication 17 Mar. 1988. Accepted for publication 29 Sept. 2001. Use of trade names does not constitute endorsement by the North Carolina Agricultural Research Service of the products named and does not imply criticism of similar ones not mentioned.

'E-mail address: Dick_Unrath@NCSU.edu
During the process of calibrating orchard airblast sprayers for actual TRV applications, we observed that foliage density was impacting our ability to achieve foliage drip point at calculated TRV water rates. We realized that it was not reasonable to use the same water rate per unit of TRV in trees with very different foliage densities. TRV water rates were therefore adjusted to achieve observed drip point in the top center area of trees. After we had conducted TRV sprayer calibrations and foliage density adjustments in many orchards of varied canopy configurations, a pattern began to emerge and a canopy density adjustment factor was added to the TRV calculations (Sutton and Unrath, 1984).

The TRV model gives growers a simple, objective and easy-to-use method of determining: 1) the volume of tree canopy on a given area of orchard, regardless of row spacing, tree size, age, etc.; and 2) the quantity of water and chemical to be used for dilute applications to effectively spray each particular orchard, regardless of pruning and tree canopy density. The TRV concept is based on the assumption that each row of trees is a wall of foliage and the quantity of water and/or chemical required can be related to the volume and density of foliage within that wall. The distance between rows of trees, the maximum tree height and the crossrow limb spread must be accurately measured. In addition, an assessment of canopy density is needed to calculate the TRV of an orchard.

Using these measurements, the TRV of any orchard can be calculated using the following model. 